\title{
ANALISIS GAYA KEPEMIMPINAN KEPALA SEKOLAH DI SMP NEGERI 6 RAMBAH SAMO KABUPATEN ROKAN HULU
}

\author{
Zikri $^{1}$, Hadriana $^{2}$, Sumarno $^{3}$ \\ 1,2,3 Universitas Riau, Pekanabaru, Indonesia \\ Izikri03zikri@gmail.com, ${ }^{2}$ hadriana@lecturer.unri.ac.id, ${ }^{3}$ sumarno@lecturer.unri.ac.id
}

\begin{abstract}
ABSTRAK
Setiap sekolah sebagai suatu organisasi memiliki kendala di luar lingkungannya yang mempengaruhi cara menjalankan aktivitasnya. Kendala tersebut dapat mengubah dan menentukan ketidakpastian lingkungan organisasi sekolah, karena membuat lingkungan menjadi dinamis dan kompleks. Ketidak pastian lingkungan membuat kepala sekolah sebagai pemimpin organisasi sulit untuk mengontrol arah institusi untuk mencapai tujuan mereka.Gaya kepemimpinan kepala sekolah merupakan salah satu faktor penting yang mempengaruhi keberhasilan sekolah. Tujuan penelitian ini adalah untuk 1) mendeskripsikan dan menganalisis gaya kepemimpinan kepala SMP Negeri 6 Rambah Samo Kabupaten Rokan Hulu dan 2) mendeskripsikan dan menganalisis faktor yang mempengaruhi gaya kepemimpinan kepala SMP Negeri 6 Rambah Samo, Kabupaten Rokan Hulu. Metode penelitian yang digunakan dalam penulisan ini adalah metode kualitatif, dengan pengumpulan datanya menggunakan wawancara mendalam, observasi dan dokumentasi. Analisis data menggunakan trianggulasi sumber, metode dan teori.Hasil penelitian ini diketahui bahwa tipe kepemimpinan yang diterapkan oleh kepala sekolah di SMP Negeri 6 Rambah Samo adalah managerial learship sesuai dengan teori Bush. Aspek pada gaya kepemimpinan yang telah berjalan dengan baik seperti inisiatif bawahan, pemberian sanksi/hukuman, pemberian penghargaan terhadap prestasi, dan rapat kerja. Namun aspek gaya kepemimpinan seperti pengambilan keputusan, menjalin komunikasi, membagi tugas, memonitoring/pengawasan pelaksanaan tugas masih perlu ditingkatkan.
\end{abstract}

Kata Kunci: gaya kepemimpinan, kepala sekolah

\section{ANALYZING THE LEADERSHIP STYLE OF THE SCHOOL PRINCIPAL AT SMP NEGERI 6 RAMBAH SAMO KABUPATEN ROKAN HULU}

\section{ABSTRACT}

As an organization, every school faces constraints outside its environment that affect the way it carries out its activities. These constraints can change and determine the uncertainty of the school organizational environment because it makes the environment dynamic and complex. This uncertainty makes it difficult for the principals as organizational leaders to control the direction of the institution to achieve its goals. The principal's leadership style is one of the crucial factors influencing the success of the school. This study aimed to describe and analyze the leadership style of the principal of SMP Negeri 6 Rambah Samo, Kabupaten Rokan Hulu and describe and analyze the factors that influenced the leadership style of the principal of SMP Negeri 6 Rambah Samo, Kabupaten Rokan Hulu. The method used in this research was a qualitative method, in which the data were collected through in-depth interviews, observation, and documentation. Then, the data were analyzed by triangulation of sources, methods, and theories. The study results indicated that 1) the leadership style applied by the principal at SMP Negeri 6 such as subordinate initiatives, sanctions/punishments, awarding achievements, and work meetings. However, aspects of leadership style such as making decisions, establishing communication, dividing tasks, monitoring/supervising the implementation of tasks still needed to be improved.

Keywords: leadership style, principal

\begin{tabular}{|c|c|c|}
\hline Submitted & Accepted & Published \\
\hline 15 Juli 2021 & 19 Oktober 2021 & 24 November 2021 \\
\hline
\end{tabular}

\begin{tabular}{|l|l|l|}
\hline Citation & $:$ & $\begin{array}{l}\text { Zikri, Z., Hadriana, H., \& Sumarno, S. (2021). Analisis Gaya Kepemimpinan Kepala Sekolah Di SMP Negeri 6 Rambah } \\
\text { Samo Kabupaten Rokan Hulu. Jurnal PAJAR (Pendidikan dan Pengajaran), 5(6), 1604-1613. DOI: } \\
\text { http://dx.doi.org/10.33578/pjr.v5i6.8469. }\end{array}$ \\
\hline
\end{tabular}

\section{PENDAHULUAN}

Pembukaan UUD 1945 alenia ke-4 telah tertuang salah satu tujuan Negara Indonesia merdeka yaitu "mencerdaskan kehidupan bangsa". Dalam upaya menciptakan generasi penerus bangsa yang memiliki kompetensi dan mampu bersaing dengan bangsa lain, maka salah satu lembaga yang berperan penting dalam hal ini adalah sekolah. Menurut UU No. 20 Tahun 2003 Bab VI Pasal 13 ayat (1) jalur pendidikan terdiri atas pendidikan formal, non formal dan informal.Sekolah sendiri termasuk kedalam jalur pendidikan formal yaitu jalur pendidikan yang 
terstruktur dan berjenjang yang terdiri dari pendidikan dasar, pendidikan menengah, dan pendidikan tinggi.

UU No. 20 Tahun 2003 Bab I, Pasal 1 Ayat (8) jenjang pendidikan formal yaitu jenjang pendidikan dasar yang merupakan jenjang pendidikan yang melandasai pendidikan menengah berbentuk Sekolah Dasar (SD), Madrasah ibtidaiyah (MI) atau sederajat lainnya, Sekolah Menegah pertama (SMP) dan Madrasah Tsanawiyah (MTS) atau sederajat lainnya. Kemudian jenjang pendidikan menengah merupakan lanjutan pendidikan dasar.Pendidikan menengah terdiri atas pendidikan menengah umum dan kejuruan.Pendidikan menengah berbentuk Sekolah Menengah Atas (SMA), Madrasah Aliyah (MA), Sekolah Menengah Kejuruan (SMK) dan Madrasah Aliyah Kejuruan (MAK) atau bentuk sederajat lainnya. Sedangkan jenjang pendidikan tinggi merupakan jenjang pendidikan setelah pendidikan menengah yang mencakup program pendidikan diploma, sarjana, magister, spesialis, dan doktor yang diselenggarakan oleh perguruan tinggi.

Seorang kepala sekolah selaku pimpinan dari semua warga sekolah yaitu siswa, karyawan tata usaha (TU) dan juga seluruh majelis guru sangat diharapkan dapat mengelola dengan baik setiap kegiatan yang ada disekolah, mulai dari perencanaan, pelaksanaan, pengawasan serta evaluasi hasil akhir dari setiap aspek kegiatan yang ada di sekolah. Sehingga sebuah sekolah sangat membutuhkan kerjasama dalam mencapai tujuan yang telah dicantuntumkan dalam visi dan misi sekolah, baik kerjasama secara vertical maupun horizontal. Maka, setiap sekolah akan memiliki cara dan prinsip yang berbeda dalam menjalankan kerjasama tersebut, sehingga hal ini tidak menutup kemungkinan sekolah akan memiliki kualitas yang berbeda dengan sekolah yang lain.

Namun dalam menjalakan setiap tugas tersebut, kerjasama antar warga sekolah juga menjadi faktor utama dalam mencapai tujuan bersama. Meskipun terdapat perbedaan prinsip kerjasama pada setiap sekolah, namun pada dasarnya kebutuhan setiap sekolah dalam menghadapi tantangan di era teknologi saat ini adalah sama. kebutuhan akan pembelajaran yang maksimal sebuah sekolah tidak akan berbeda meskipun posisi sekolah tersebut berbeda yaitu dikota dan didaerah. Bahkan struktur organisasi sebuah sekolah tidak ada perbedaan meskipun lokasi dan kondisinya berbeda dengan sekolah lain. Misalnya seorang kepala sekolah, dapat kita lihat dalam Permendikbud Nomor 6 Tahun 2019 tentang Pedoman Organisasi dan Tata Kerja Satuan Pendidikan Dasar dan Menengah, pasal 1 ayat (14) berbunyi "Kepala Sekolah adalah pemimpin satuan pendidikan yang mempunyai tugas melaksanakan tugas manajerial, pengembangan kewirausahaan dan supervisi kepada guru dan tenaga kependidikan". Artinya dalam struktur sebuah sekolah, fungsi dan peran kepala sekolah akan sama meskipun lokasi sekolah berbeda seperti dipusat dan didaerah.

Tugas kepala sekolah pada dasarnya memiliki kesamaan, namun kondisi yang di hadapi setiap sekolah berbeda, seperti keterbatasan sarana dan prasarana hingga keterbatasan ekonomi sekolah, maka dalam hal ini akan membutuhkan gaya kepemimpinan seorang kepala sekolah sehingga dapat memanajemen permasalahaan tersebut. Seperti yang dihadapi oleh kepala sekolah SMP Negeri 6 Rambah Samo Kabupaten Rokan Hulu, dengan jarak sekitar21 KMdari ibu kota Kabupaten. Mungkin jarak tersebut tidak akan menjadi persoalan apabila akses yang dilalui mulus, akan tetapi jalannya sangat sulit dilewati apabila musim hujan.

Kemudian SMP Negeri 6 Rambah samo ini merupakan pemisahan dari SDN 035 Rambah Samo yang pada awalnya merupakan Satu Atap (SATAP).Keberadaan SMP Negeri 6 ini diharapkan bisa memenuhi hak setiap warga disana dalam memperoleh pendidikan. Hal ini dikarenakan akses untuk mejangkau ke SMP lain sangat jauh dan tidak memungkinkan siswa tamat SD untuk melewatinya

Meskipun dengan diterapkannya sitem zonasi pada penerimaan siswa baru, akan tetapi dengan jarak sekolah tersebut jauh dari Sekolah Dasar (SD) yang lain seperti Sekolah Dasar Negeri 18 Rambah Samo yang termasuk zonasi SMPN 6 Rambah Samo lebih memilih masuk ke SMPN 2 Rambah Samo, maka siswa yang diharapkan masuk ke SMP 6 tersebut hanya tamatan dari SD 35 yang pada umumnya hanya masyarakat sekitar. 
Sehingga dengan demikian, permasalahan yang muncul yaitu jumlah siswa yang sedikit pada setiap kelasnya. Dengan demikian, akan berdampak pada pendapatan sekolah dari Biaya Operasional Sekolah (BOS) yang merupakan satusatunya sumber pendapatan sekolah, yang mana dana BOS yang di terima oleh sekolah sesuai dengan jumlah peserta didik.

Kemudian seorang kepala sekolah tidak dapat menjalankan perannya dengan baik dan maksimal, hal ini dikarenakan beberapa masalah tersebut sangat menghambat kepala sekolah dalam mengaplikasiakan peranannya. Dalam peranananya kepala sekolah tidak diberikan jam untuk mengajar, agar kepala sekolah bisa berfokus pada tugasnya sebagai pemimpin. Namun pada kenyataannya di SMPN 6 Rambah Samo Kepala Sekolah selalu masuk kelas sebagai pengajar untuk menggantikan Guru yang tidak hadir pada setiap mata pelajaran. Peran kepala sekolah sebagai pengawas atau supervisor tidak dapat dilaksanakan dengan sepenuhnya, hal ini karenakan guru mencari pekerjaan sampingan untuk menambah keuangan keluarga. Seorang kepala sekolah memahami setiap permasalahan yang dialami oleh bawahannya melalui komunikasi yang baik, sehingga hal ini menjadi salah satu faktor yang mempengaruhi gaya kepemimpinan kepala sekolah yaitu memperhatikan staf secara individu serta memberikan perhatian terhadap pribadi, memperlakukan karyawan secara individual, melatih, dan menasehati. Dari segi sarana dan prasarana sekolah tersebut masih jauh tertinggal dari sekolah lain, seperti gedung sekolah yang masih bangunan lama. Kemudian sekolah juga tidak memiliki gedung untuk perpustakaan, laboratorium dan UKS yang memadai.

Dengan berbagai permasalahan tersebut, penulis merasa tertarik untuk mengetahui lebih dalam lagi gaya kepemimpinan kepala sekolah dalam menghadapi permasalahan yang ada di sekolah ini dan berharap bisa memberikan solusi untuk kedepannya dengan penelitian yang berjudul "Analisis Gaya Kepemimpinan Kepala SMP Negeri 6 Rambah Samo Kabupaten Rokan Hulu".

\section{KAJIAN TEORETIS}

\section{Analisis}

Menurut Harahap (2004) Analisis adalah suatu upaya untuk memecahkan atau menguraikan sesuatu unit menjadi berbagai unit terkecil. Artinya analisis akan mengurai sesuatu hingga ke bagian terkecil. Menurut Peter Salim dan Yenni Salim (2002) analisis adalah proses pemecahan masalah yang dimulai dengan hipotesis (dugaan) sampai terbukti sebenarnya melalui beberapa kepastian (pengamatan,percobaan, dan sebagainya). Dengan kata lain, analisis yaitu pemecahan masalah dengan menduga sebab awal dan mencari kepastian terhadap dugaan tersebut.

Dari beberapa pengertian yang diatas, dapat ditarik kesimpulan bahwa pada dasarnya analisis itu dilaksanakan untuk mencari sebuah kebenaran terhadap suatu peristiwa, baik itu karangan ataupun perbuatan seseorang. Analisis yang dilakukan bisa diawali oleh dugaan yang harus dicari kebenarannya melalui menguraikan berbagai fakta hingga ke unit terkecil. Analisis dapat juga dilakukan dengan pengamatan terhadap tanda-tanda setiap komponen yang memiliki tujuan terpadu atau sama.

\section{Gaya Kepemimpinan}

Menurut Young (Kartono, 2003) kepemimpinan adalah bentuk dominasi yang didasari atas kemampuan pribadi yang sanggup mendorong atau mengajak orang lain untuk berbuat sesuatu yang berdasarkan penerimaan oleh kelompoknya, dan memiliki keahlian khusus yang tepat bagi situasi yang khusus. Jadi dari berbagai pengertian tersebut dapat kita simpulkan bahwa seorang pemimpin harus memiliki berbagai cara untuk dapat mempengaruhi bawahannya agar bisa bekerjasama dalam mencapai suatu tujuan.

Sopiah (2008:108) Stogdil dalam survei nya mengenai riset dan teori kepemimpinan menyatakan bahwa "jumlah batasan atau defenisiyang berbeda-beda mengenai kepemimpinan hampir sama banyaknya dengan jumlah orang yang mencoba memberikan batasan tentang konsep tersebut". Sopiah (2008:108) ada tiga implikasi penting dari batasan kepemimpinan, yaitu:

1. Kepemimpinan harus melibatkan orang lain, bawahan atau pengikut. Karena kesediaan 
mereka menerima pengarahan dari pemimpin anggota kelompok membantu menegaskan status pemimpin dan memungkinkan terjadinya proses kepemimpinan. Tanpa bawahan maka semua sifat kepemimpinan seorang menejer akan menjadi tidak relevan.

2. Kepemimpinan mencakup distribusi kekuasaan yang tidak sama diantara pemimpin dan anggota kelompok. Pemimpin mempunyai wewenang untuk mengarahkan beberapa aktifitas anggota kelompok, yang caranya tidak sama antara pemimpin yang satu dengan yang lain.

3. Disamping secara sah mampu memberikan perintah atau pengarahan kepada bawahan atau pengikutnya, pemimpin juga dapat mempengaruhi bawahan dengan berbagai cara.

\section{Fungsi Kepemimpinan}

Fungsi kepemimpinan menurut Kartono (2003) adalah memandu, menuntun, membimbing, membangun, memberi motivasi kerja, memberikan pengawasan yang efisien dan membawa pengikutnya kepada sasaran yang dituju. Dalam mewujudkan fungsi-fungsi kepemimpinan secara integral, sebagaimana telah dikemukan diatas akan berlangsung aktivitas kepemimpinan. Apabila aktivitas tersebut dipilah-pilah maka akan terlihat gaya kepemimpinannya dengan pola masingmasing.

\section{Gaya Kepemimpinan}

Gaya Kepemimpinan ini terdiri dari dua suku kaya yaitu kata Gaya dan kata Kepemimpinan.Sedarmayanti (2010: 130) berpendapat bahwa Gaya itu adalah sikap, gerakan, tingkah laku, sikap yang elok, gerak-gerik yang bagus, kekuatan, kesanggupan untuk berbuat baik. Hal dapat diartikan bahwa tingkah laku seorang pemimpin dalam menyikapi setiap permasalahan yang dihadapi baik secara vertikal maupun horizontal dalam sebuah organisasi akan menjadi gaya dalam kepemimpinannya. John Adair dalam Susanto dan Aisiyah (2010:19) menyatakan bahwa seorang pemimpin adalah seseorang yang memiliki kepribadian dan watak tertentu yang sesuai dengan situasi umum, didukung dengan kemampuan teknis dan pengalaman relevan, yang diperlukan untuk menuntun kelompok mencapai tujuan dan dalam waktu yang bersamaan memelihara dan membangun persatuan tim.

Aissah Qomaria Azis dan Suwatno (2019:248) mengatakan bahwa penelitian dan teori kepemimpinan dapat diklasifikasikan dalam pendekatan sifat, perilaku dan situasionalcontigency.Maka dalam penilitan ini, pendekatan yang digunakan adalah pendekatan perilaku yang mana pendekatan perilaku membahas mengenai beberapa perilaku yang efektif dilakukan oleh pemimpin dalam menjalankan kepemimpinannya, perilaku pemimpin bisa dipelajari sehingga bisa dibentuk dengan pembiasaan yang disengaja.

\section{Tipe Gaya Kepemimpinan Kepala Sekolah}

Menurut Hasibuan (2014) terdapat beberapa macam gaya kepemimpinan yaitu sebagai berikut:

1. Kepemimpinan otoriter

Kepemimpinan Otoriter adalah jika kekuasaan atau wewenang, sebagian besar mutlak tetap berada pada pimpinan atau kalau pimpinan itu menganut sistem sentralisasi wewenang. Pengambilan keputusan dan kebijaksanaan hanya ditetapkan sendiri oleh pemimpin, bawahan tidak diikutsertakan untuk memberikan saran, ide, dan pertimbangan dalam proses pengambilan keputusan.

2. Kepemimpinan partisipasi

Kepemimpinan Partisipasi adalah apabila dalam kepemimpinan-nya dilakukan dengan cara persuasif, menciptakan kerja sama yang serasi, menumbuhkan loyalitas, dan partisipasi para bawahan. Pemimpin memotivasi bawahan agar merasa ikut memiliki perusahaan. Bawahan harus berpartisipasi memberikan saran, ide, dan pertimbangan dalam proses pengambilan keputusan.

3. Kepemimpinan delegasi

Kepemimpinan Delegasi apabila seorang pemimpin mendelegasikan wewenangnya kepada bawahan dengan agak lengkap.Dengan demikian, bawahan dapat mengambil keputusan dan kebijaksanaan dengan bebas atau leluasa dalam melaksanakan pekerjaannya. Pemimpin tidak peduli cara bawahan mengambil keputusan dan mengerjakan pekerjaannya, sepenuhnya diserahkan kepada bawahan. 


\section{Faktor-Faktor Yang Mempengaruhi Gaya Kepemimpinan}

$\begin{array}{ccr}\text { Seorang } & \text { pemimpin } \\ \text { manajemen } & \text { dalam } & \begin{array}{r}\text { memiliki } \\ \text { menjalankan }\end{array}\end{array}$
kepemimpinnannya. Menurut Siagian (2014:48) ada tiga faktor yang mempengaruhi perencanaan sumber daya manusia yaitu faktor dari luar organisasi (Eksternal), faktor yang berasal dari dalam lingkungan organisasi (internal) dan faktor persediaan karyawan:

1. Faktor Eksternal

Suatu organisasi agar dapat melaksanakan misi dan tujuannya maka harus memperhitungkan faktor-faktor eksternal organisasi seperti situasi ekonomi, sosial budaya, politik, peraturan undangundang, teknologi dan persaingan.

2. Faktor Internal

Faktor internal mencakup keseluruhan kehidupan organisasi/lembaga yang dapat dilakukan, baik pemimpin maupun anggota organisasi yang bersangkutan.

3. Faktor Persedian Karyawan

Faktro persediaan karyawan ini berkaitan dengan sumber daya manusia yang tersedia dalam sebuah organisasi/lembaga. Hal ini ini akan sangat mempengaruhi terhadap hasil atau output dari sebuah organisasi.

\section{METODE PENELITIAN}

Pendekatan yang digunakan pada penelitian ini adalahdeskriptif kualitatif, hal ini dikarenakan pengumpulan data dan analisisnya lebih bersifat kualitatif. Metode deskriptif bertujuan untuk memahami makna dibalik data yang tampak. Penelitian ini dilakukan untuk memperoleh informasi tentang bagaimana gaya kepemimpinan kepala sekolah di SMP Negeri 6 Rambah Samo Kabupaten Rokan Hulu. Penelitian ini dilakukan di SMP Negeri 6 Rambah Samo Kabupaten Rokan Hulu, dan penelitian ini dilaksanakan ada bulan Februari - Juli 2021. Responden dalam penelitian ini adalah kepala sekolah, majelis guru dan pengurus komite yang berjumlah di SMP Negeri 6 Rambah Samo Kabupaten Rokan Hulu.

Sumber data dalam penelitian ini adalah data primer didapatkan melalui kegiatan wawancara dengan subjek penelitian dan dengan observasi atau pengamatan langsung di lapangan.
Data primer dikumpulkan melalui wawancara dengan wawncara kepala sekolah yaitu Drs. H. Sukiman, dan Guru-guru diantaranya Ali Imron, S.Pd, Drs. Eduar Ruslan, Titimarni, S.Pd, dan Lestiana, A.Ma. Selanjutnya data sekunder dalam penelitian ini yaitu data tentang data kehadiran kepala sekolah, rapat/absensi, dan profil sekolah.Selanjutnya, data ini sebagai data pendukung yang di peroleh melalui pengamatan peneliti dilapangan. Analisis data dalam penelitian ini mengarah pada analisis deskriptif atau analisis yang menggambarkan informasi faktual. Untuk itu teknik analisa data menggunakan teknik analisis deskriptif kualitatif dan tidak menguji hepotesis maupun hubungan antar variabel. Setelah data dikumpulkan, maka penulis akan menganalisa setiap faktor yang mempengaruhi gaya kepemimpinan kepala sekolah.

\section{HASIL DAN PEMBAHASAN Triangulasi Sumber}

Sugiyono (2017:125) triangulasi sumber untuk menguji kredibilitas data dengan cara mengecek data yang diperoleh melalui beberapa sumber. Triangulasi sumber berarti membandingkan serta mengecek derajat kepercayaan suatu hasil penelitian dari informasi yang berasal dari informan yang berbeda dengan metode wawancara.

Peneliti melakukan wawancara dalam pengambilan data analisis gaya kepemimpinan kepala sekolahdi SMP 6 Rambah Samo Kabupaten Rokan Hulu untuk mengetahui bagaimana gaya kepemimpinan kepala sekolah dan faktor apa saja yang mempengaruhu gaya kepemimpinannya.

Peneliti melakukan wawancara dengan kepala sekolah yakni bapak Drs. H. Sukirman tentang bagaimana bapak setiap kali bapak mengambilkeputusan, dalam membagi tugas, apakah guru dan staf memiliki inisiatif dalam melaksanakan tugas, memberikan sanksi kepada guru dan staf yang melanggar peraturan sekolah, memberikan motivasi kepada guru dan staf, bagiamna cara menjalin komunikasi yang baik dengan guru dan staf, mengawasi kegiatan di sekolah serta kapan saja yang menjadi momen untuk diadakannya rapat sekolah.

Dari wawancara bersama responden, dapat disimpulkan terkait bagaimana gaya 
kepemimpinan kepala sekolah SMP 6 Rambah Samo dalam memimpin sekolah dengan tanggung jawab, memastikan guru dan staf mempunyai inisiatif yang tinggi dalam melaksanakan tugas, kepala sekolah selalu berusaha menjalin komunikasi yang baik dengan guru dan staf serta memastikan komunikasi yang vertikal dan horizontal terjalin dengan baik, setiap tugas dan kegiatan sekolah selalu dimonitoring oleh kepala sekolah dan melakukan evaluasi kinerja serta kepala sekolah melakukan rapat setiap awal dan akhir semester serta melakukan rapat di agendaagenda sekolah yang lainnya sesuai dengan kebutuhan yang dibutuhkan sekolah.

Terkait faktor - faktor apa saja yang mempengaruhi gaya kepemimpinan kepala sekolah SMP 6 Rambah Samo peneliti melakukan wawancara kepada kepala sekolah, guru dan staf sebagai informannya. Dalam hal ini bapak Drs. H. Sukirmansebagai kepala sekolah terkait 2 faktor yang menjadi faktor - faktor kepemimpinan yakni internal dan eksternal. Dari hasil penelitian yang dilakukan dari wawncara peneliti dengan kepala sekola, guru dan staf yang ada terkait faktor yang mempengaruhi gaya kepemimpinan kepala sekolah SMP 6 Rambah Samo dapat disimpulkan bahwa:

Faktor internal gaya kepemimpinan kepala sekolah SMP 6 Rambah Samo Kab. Rokan Hulu ialah faktor psikologis terkait seorang pemimpin harus mampu memandang sisi psikologis yang dimiliki untuk pegawai yakni guru dan staf, seorang pemimpin harus mampu memotivasi, mampu mengambil keputusan yang tepat dan cepat serta mampu berkomunikasi yang baik, baik secara vertikal maupun horizontal.

Sedangkan faktor eksternal yang mempengaruhi gaya kepemimpinan kepaala sekolah SMP 6 Rambah Samo Kab. Rokan Hulu ialah keadan ekonomi yang berkaitan dengan keuangan sekolah, politik sekolah terkait mendampingi siswa diorganisasi yang ada di Sekolah, sosial budaya lingkungan sekitar, peraturan perundang-undangan yang mengatur peraturan sekolah, tekhnoligi yang daat dimanfaatkan baik dari siswa maupun guruserta persaingan prestasi kualitas guru yang menjadi faktor eksternal dalam memimpin sebuah sekolah sangat berpengaruh untuk menciptakan sekolah yang berkualitas.

\section{Triangulasi Metode}

Mudjia Rahardjo (2012) Triangulasi metode dilakukan dengan cara membandingkan informasi atau data dengan cara yang berbeda. Dalam penelitian kualitatif peneliti menggunakan metode wawancara, obervasi, dan survei.Dengan menggunakan triangulasi metode keabsahan suatau data peneliti dicek dengan menggunakan metode wawancara dan observasi, untuk memperoleh informasi yang utuh dan akurat.

\section{Triangulasi Teori}

Moleong (2005:331) Triangulasi teori yaitu pemeriksaan data dengan menggunakan perspektif lebih dari satu teori dalam membahas permasalahan yang dikaji.Triangulasi teori mensingkronisasi hasil penelitian dengan memanfaatkan dua teori atau lebih yang kemudian dipadukan untuk memperoleh hasil yang lebih komprehenshif terhadap data yang diperoleh.

\section{Pembahasan}

Kepemimpinan merupakan seni mengatur sebuah organisasi, agar anggota berkotmitmen penuh, mempunyai motivasi kerja serta berinisiatif yang tinggi dalam menjalankan tugas, sehingga keberhasilan sebuah kepemimpinan dalam mengatur organisaiberpengaruh terhadap kinerja atau keberhasilan sebuah organisasi.

Seorang pemimpin mempunyai peran besar dalam sebuah kepemimpinan organisasi, maka seseorang pemimpin harus mampu dan dapat memainkan peranannya, teat dlam mengambil keputusan, serta seorang pemimpin harus mampu menggali potensi-potensi yang ada pada dirinya dan memanfaatkannya di dalam unit organisasi agar mampu mencapai tujuan organisasi yang telah ditetapkan bersama.

Berdasarkan hasil wawancara dan observasi SMP Negeri 6 Rambah Samo Kab. Rokan Hulu memiliki gaya kepemimpinan tersendiri dalam mencapai tujuan bersama, serta memiliki faktor -faktor gaya kepemimpinan dalam memajukan sekolah agar lebih berkualitas.

Gaya Kepemimpinan Kepala Sekolah SMP Negeri 6 Rambah Samo Kab. RokanHulu. 
Efektivitas gaya kepemimpinan tidak hanya tergantung pada tindakan pemimpin dalam mendiagnosis dan menerapkan perilaku kepemimpinan sesuai situasi yang dihadapi. Berdasarkan hasil wawancara dan observasi berikut ini adalahgaya kepemimpinan kepala sekolah SMP Negeri 6 Rambah Samo kab. Rokan Hulu :

1. Pengambilan Keputusan

Dari wawancara bersama kepala sekolah Bapak Drs. H. Sukirman mengatakan bahwa:

"Biasanya saya sebelum mengambil keputusan akan bermusyawarah dengan seluruh guru dan staf sekolah terhadap hal-hal yang akan dihadapi oleh sekolah jika keputusan itu harus dimusyawarahkan terlebih dahulu. Jika pengambilan keputusan tidak memerlukan musyawarah maka kepala sekolah langsung mengambil keputusanhanya diputuskan dengan beberapa orang yang bersangkutan. Hal ini sesuai dengan program pembahasan jika membahas tentang keuangan maka akan membahas dengan kepala TU dan bendahara sekolah. Atau dalam hal mengambil keputusan bisa dilakukan dengan mencari tau terlebih dahulu apa permasalahannya, mencari tau apa solusinya, solusi yang ada kita pilih yang tepat bagaimana dan setiap permasalahan yang sudah menemukan solusi akan dievaluasi kembali, pengambilan keputusan dengan cara ini juga dilakukan dalam hal mengambil keputusan pembuatan program sekolah.”

Sehingga, dari hasil penelitian yang dilakukan di SMP Negeri 6 Ramban diketahui bahwa pengambilan keputusan yang dilakukan kepala sekolah telah berdasarkan identifikasi, pengumpulan fakta-fakta, mempertimbangkan masalah dari hasil musyawarah, meskipun berfokus pada tata kelola tugas-tugas saja dan tidak begitu fokus pada visi yang ada disekolah.

\section{Pembagian Tugas}

Dari hasil wawancara bersama salah satu majelis guru yaitu bapak Ali Imron, S.Pd mengatakan bahwa:

“Kepala sekolah kalau ngasih tugas ya diberikan sesuai dengan kebutuhan dan tanggung jawab setiap guru dan staf".

Berdasarkan hasil wawancara kepala sekolah dan majelis guru di SMP Negeri 6 Rambah Samo memeberikan perintah melalui dua cara, bermusyawarah dan pemberian tugas langsung kepada yang bertanggung jawab. Pemberian tugas yang dilakukan dengan cara bermusyawarah misalnya pembuatan jadwal piket sekolah, penetapan wali kelas setiap kelas, penentuan guru pengampuh mata pelajaran kelas dan lain - lain. Pemberian tugas langsung kepada yang bersangkutan misalnyaberkaitan dengan administrasi sekolah maka tugas diberikan kepada staf tata usaha sekolah.

3. Inisiatif dalam melaksanakan tugas

Dari hasil wawancara bersama majelis guru yaitu Ibuk Lestiana, A.Ma mengatakan bahwa:

"Setiap guru dan staf berinisiatif melaksanakan tugas-tugas serta memberikan masukan kepada kepala sekolah ketika terdapat kendala selama program sekolah berjalan, ini juga karena kepala sekolah tidak menganggap kami asing sebagai warga sekolah”.

Inisiatif artinya munculnya suatu tindakan dalam diri seseorang untuk menjalankan suatu tugas tanpa adanya perintah lagi kepada bawahan dari atasan.Berdasarkan hasil wawancara dan observasi penulis guru dan staf sekolah mempunyai inisiatif untuk bertanggung jawab melaksanakan tugas-tugasnya. Guru bertanggung jawab menjadi tenaga pengajar. Staf bertanggung jawab mengatur administrasi sekolah.

4. Pemberian sanksi pelanggaran

Dari hasil wawancara majelis guru yaitu ibuk Mardiana, SP mengatakan bahwa:

"Apabila guru melakukan kesalahan sepertihalnya guru terlambat, tidak melaksanakan tugas atau yang lainnya kepala sekolah akan memberikan peringatan, nasehat dan arahan".

Berdasarkan hasil wawancara dan observasi Kepala sekolah SMP 6 Rembah Samo dalam memberikan sanksi pelanggaran 
kedisiplinan tidak memberikan sanksi hukuman yang berat tetapi diberikan arahan dan teguran agar tidak mengulangi kembali kesalahan yang sama. Namun apabila guru atau staf sudah melampui batas sampai berbuat asusila maka sanksi yang diberikan adalah dikeluarkan dari sekolah

5. Memberikan motivasi kerja

Dari hasil wawancara dengan TU sekolah yaitu Ibuk Risa mengatakan bahwa:

"Dalam hal motivasi saya sebagai staf akan diberikan kepercayaan penuh untuk mengatur administrasi sekolah dan mampu bekrja bekerja dengan baik dan profesional"

Sehingga hasil wawancara dan observasi kepala sekolah SMP 6 Rambah Samo dalam memotivasi guru dan staf dilakukan dengan menggunakan tiga cara yakni memberikan apresiasi, memberikan kepercayaan penuh terhadap tugas yang diberikan dan membentuk team building.

\section{Menjalin Komunikasi}

Dari hasil wawancara bersama majelis guru Bapak Ali Imron, S.Pd mengatakan bahwa:

"Komunikasi antara kepala sekolah dengan guru dilakukan dengan memberikan informasi yang jelas terkait tugas sekolah, memberikan intruksi tugas dengan jelas dan memberikan arahan-arahan terkait programprogram sekolah yang akan dijalankan bersamasama".

Dari hasil penelitian, komunikasi yang dibangun oleh kepala sekolah SMP 6 Rambah Samo menjadikan komunikasi sebagai penyampaian pesan yang mengandung arahan, intruksi, ide, gagasan, pikiran, fakta dan pendapat.Komunikasi yang dibangun oleh kepala sekolah baik secara vertikal maupun horizontal diharapkan mampu menjalin hubungan yang baik antara kepala sekolah dengan guru dan staf, guru dengan guru, staf dengan staf ataupun guru dengan staf.

7. Memonitoring pelaksanaan tugas

Dari hasil wawancara bersama kepala sekolah Bapak Drs. H. Sukirman mengatakan bahwa:

"Saya sebagai kepala sekolah masih banyak keterbatsaan dalam mengawasi guru dan staf, masih pada mengawsi apakah kegiatan belajar mengajar sudah berlangsung dengan baik atau belum. Masih banyak hal yang harus dipenuhi apalagi dalam memenuhi sarana dan prasarana sekolah serta meningkatkan kualitas tenaga pengajar dengan memperhatikan moral, mental, fisik dan artistik yang seharusnya menjadi pengawasan saya"

Dari hasil wawancara dan observasi kepala sekolah dalam memonitoring pelaksanaan tugas yang dilaksanakan guru dan staf dilakukan dengan cara supervisi dan evaluasi kinerja. Supervisi dengan mengawasi satu persau kinerja guru dan staf sedangkan evaluasi menilai kekurangan dan kebaikan tugas yang sudah dilaksanakan oleh guru dan staf sekolah. Memonitoring guru dan staf dengan pengawasan supervisi dan evaluasi akan meningkatkan kualitas profesional guru dan staf dalam bekerja

\section{Rapat sekolah}

Dari hasil wawancara bersama majelis guru Bapak Ali Imron, S.Pd mengatakan bahwa:

"Kadang saya tidak dan bebeapa guru atau staf tidak dapat hadir dalam rapat hal ini dikarenakan tidak ada jam mengajar atau piket disekola serta harus menyelesaikan pekerjaan diluar sekolah, jika rapatnya-rapat dadakan. Tetapi jika rapat itu terjadwal seperti diawal dan akhir smester,penentuan wali kelas atau jam pelajaran maka semua guru dan staf harus hadir dalam rapat."

Dari hasil wawancara dan observasi rapat sekolah yang dipimpin oleh kepala sekolah SMP 6 Rambah Samo dilaksanakan pada awal semester ganjil sebagai pembentukan jadwal mengajar mata pelajaran terkait, menentukna wali kelas dan pembuatan program selama satu tahun pembelajaran. Rapat yang di setiap akhir semester sebagai evaluasi gru dan staf sekolah. Rapat-rapat program atau dadakan lainnya sesuai dengan 
kebutuhan. Rapat dapat dilaksanakan dengan sedemikian rupa agar dapat berjalan secara optimal dan berkualitas.

Faktor - Faktor Gaya Kepemimpinan Kepala Sekolah SMP Rambah Samo Kabupaten Rokan Hulu.

Faktor eksternalgaya kepemimpinan

1. Kondisi ekonomi SMP Negeri 6 Rambah Samo

Setiap kegiatan pasti membutuhkan biaya, biaya yang mencukupi akan mempengaruhi hasil dari setiap kegiatan tersebut. Begitu juga dengan kegiatan pembelajaran di sekolah, biaya yang mencukupi akan mempengaruhi proses pembelajaran dan kualitas output yang dihasilkan. di SMP Negeri 6 Rambah Samo, kondisi ekonomi atau biaya Pendidikan merupakan salah satu masalah yang dihadapi hingga saat ini. Hal ini dikarenakan sumber pendapatan sekolah hanya bertumpu pada dana BOS yang didapatkan oleh sekolah setiap tahunnya. Seperti kita ketahui bersama bahwa dana BOS dihitung per-jumlah siswa dengan nominal $\mathrm{Rp} 1.100 .000$, dengan jumlah siswa sebanyak 29 orang maka sekolah akan memperoleh dana BOS sebesar Rp 31.900 .000 pertahun(Hasil observasi lapangan, 2021).

2. Sosial dan budaya masyarakat

Sebuah sekolah tidak akan bisa berjalan dengan baik apabila tidak bisa menciptakan kerjasama dengan masyarakat setempat. Sebuah Kerjasama akan terjalin dengan baik apabila kedua belah pihak memiliki komitmen bersama untuk menciptakan dunia Pendidikan yang lebih baik kedepannya. Hal ini merupakan salah satu aspek yang sangat diperhatikan oleh pihak SMP Negeri 6 Rambah Samo, selalu berusaha untuk menjalin Kerjasama agar bisa membangun dunia Pendidikan yang lebih baik.Kepala sekolah senantiasa mengajak masyarakat untuk berkontribusi dalam membangun SMP tersebut, namun keadaan masyarakat yang Sebagian masih berpegang pada pendirian masing-masing maka mengakibatkan beberapa Kerjasama belum berjalan dengan semestinya. Hal ini dibuktikan dengan tidak berjalannya iuran setiap siswa yang telah disepakai bersama didalam rapat komite bersama wali murid.Kemudian, usaha untuk memperbaiki jalan menuju sekolah dengan memanfaatkan perusahan tetangga.

3. Teknologi

Berdasarkan observasi diketahui bahwa jenis teknologi yang digunakan disekolah belum bervariasi, masih menggunakan whatsapp, sosial media, dan belum ada fasilitas laboratorium computer. Sehingga Kepala Sekolah dan guru di SMP Negeri 6 Rambah Samo Kabupaten Rokan Hulu masih terkendala dan kesulitan dalam menentukan jenis teknologi karena pemahaman akan media dan sumber belajar teknologi yang digunakan juga masih rendah. Selain itu berdasarkan wawancara yang dilakukan dengan kepala sekolah juga diketahui bahwa belum ada melakukan analisis kebutuhan infrastruktur (sarana dan prasarana) yang mendukung penerapan teknologi di sekolah

\section{Persaingan}

Berdasarkan observasi diketahui bahwa guru kurang memiliki persaingan internal yang menumbuhkan prestasi hal ini dapat dilihat dari tidak adanya program reward yang diberikan kepada guru sehingga antar guru tidak memiliki persaingan untuk saling berprestasi di SMP Negeri 6 Rambah Samo Kabupaten Rokan Hulu

Faktor internal gaya kepemimpinan

1. Faktor Psikologis

Berdasarkan hasil wawancara dan observasi kepalas sekolah SMP 6 Rambah Samo harus dapat memahami secara psikolgis guru dan staf dalam memberikan motvasi, setiap mengambil kepututusan serta mampu berkomunikasi yang baik dengan guru dan staf sekolah. Dalam pengambilan keputusan adalah suatu proses penting dalam implementasi kepemimpinan berkaitan dengan kondisi personal dan situasional pemimpin dalam proses pengelolaan sekolah yang berkualitas.

2. Persepsi tentang lingkungan kerja yang sehat

Berdasarkan hasil observasi dan wawancara kepala sekolah SMP 6 Rambah Samo dalam kepala sekolah berpendapat bahwa dalam menciptakan lingkunagn kerja yang sehat memberikan kenyaman lingkungan baik fisik maupun nonfisik.Lingkungan fisik berkaitan dengan sarana dan prasarana sekolah.Sedangkan non fisik berhubungan dengan menjalin hubungan yang baik antar guru dan staf agar menciptakan lingkungan yang kondusif dan nyaman dalam 
bekerja guna mencapai tujuan bersama.Secara umum kepala sekolah beranggapan bahwa lingkungan kerja yang ada belum mampu menumbuhkan gairah dalam bekerja setiap guru pada saat tertentu. Apabila itu terjadi, maka kepala sekolah berupaya untuk memaksimalkan komunikasinya agar ia dapat mendorong staff menjalankan pekerjaannya dan lingkungan kerja menjadi baik kembali.

\section{SIMPULAN DAN REKOMENDASI}

Dari hasil penelitian ini, maka dapat disimpulkan bahwaGaya kepemimpinan seorang kepala sekolah di SMP Negeri 6 Rambah Samo dianggap cukup baik.Tipe kepemimpinan yang diterapkan oleh kepala sekolah di SMP Negeri 6 Rambah Samo adalah managerial learship sesuai dengan teori Bush. Aspek pada gaya kepemimpinan yang telah berjalan dengan baik seperti inisiatif bawahan, pemberian sanksi/hukuman, pemberian penghargaan terhadap prestasi, dan rapat kerja. Namun aspek gaya kepemimpinan seperti pengambilan keputusan, menjalin komunikasi, membagi tugas, memonitoring/pengawasan pelaksanaan tugas masih perlu ditingkatkan. Hal ini terlihat dari bagaimana kepala sekolah mengambil keputusan dengan bermusyawarah sesuai dengan kebutuhan, pembagian tugas yang dimusyawarahkan dan sesuai tanggungjawab, selain itu fungsi kepala sekolah masih terdapat kendala dalam memonitoring setiap tugas yang dilakukan oleh guru dikarenakan berbagai faktor.

Faktor-faktor yang mempengaruhi kepemimpinan kepala sekolah SMP Rambah Samo Kabupaten Rokan Hulu diantaranya adalah faktor internal dan faktor eksternal.Faktor internal diantaranya; 1) faktor psikologis yaitu kondisi psikologis kepala sekolah itu sendiri dalam memimpin, mengambil keputusan, ataupun mengimplementasikan kepemimpinannya. 2) persepsi tentang lingkungan kerja yang sehat yaitu apabila kepala sekolah merasakan bahwa kondisi kerja tidak menyenangkan maka dapat berdampak pada kondisi kepemimpinannya.Sedangkan faktor eksternal dalam penelitian ini adalah 1) kondisi ekonomi 2) Sosial dan budaya masyarakat. 3) Teknologi, dimana masih terbatasnya jenis teknologi yang digunakan disekolah belum bervariasi. 4) Persaingan prestasi antar guru.

\section{DAFTAR PUSTAKA}

Arikunto, S. (2002). Prosedur Penelitian: Suatu pendekatan Praktik. Jakarta: Rineka Cipta.

Azis, A. Q., \& Suwatno. (2019). Pengaruh Gaya Kepemimpinan Kepala Sekolah terhadap Kinerja Guru di SMK Negeri Bandun. Manper: Jurnal Pendidikan Manajemen Perkantoran, (2) 2, 246-253.

Harahap, S.S. (2004). Analisis Kritis Atas Laporan Keuangan. Jakarta: PT Raja Grafindo Persada.

Kartono, K. (2003). Pemimpin dan Kepemimpinan (Apakah Kepemimpinan Abnormal Itu). Jakarta: PT Raja Grafindo Persada.

Salim, P., \& Yenny, S. (2002). Kamus Bahasa Indonesia Kontemporer. Jakarta: Modern English Press

Salinan Permendikbud Nomor 6 Tahun 2019 tentang Pedoman Organisasi dan Tata Kerja Satuan Pendidikan Dasar dan Menengah,

http://kemendikbud.go.id/main/files/dowload/f7ff 9f28e7236c7 [accessed date: 19 januari 2021]

Sedarmayanti. (2001). Sumber Daya Manusia dan Produktivitas Kerja. Bandung: Mandar Maju

Siagian, S. P. (2014). Manajemen Sumber Daya Manusia. Jakarta : Bumi Aksara

Sopiah. (2008). Perilaku Organisasi. Yogyakarta: Andi.

Sugiyono. (2017). Metode Penelitian Pendidikan Kuantitatif, Kualitatif dan $R \& D$. Bandung: Alfabeta.

Susanto \& Aisiyah. (2010). Analisis Pengaruh Kepemimpinan dan Budaya Kerja Dengan Motivasi sebagai Variabel Intervening Terhadap Kinerja Karyawan di Kantor Pertanahan Kabupaten Kebumen. Magistra No. 74 Tahun XXII. ISSN 02159511. hal. 35-37. Sekolah Tinggi Pertanahan Nasional Yogyakarta.

UU No. 20 Tahun 2003 http://luk.staff.ugm.ac.id [accessed date: 15 januari 2021] 